\title{
Vesselplasty: A New Minimally Invasive Approach to Treat Pathological Vertebral Fractures in Selected Tumor Patients - Preliminary Results
}

\author{
Vesselplastie: ein neues minimalinvasives Verfahren zur Behandlung pathologi- \\ scher Frakturen bei ausgewählten Tumorpatienten - vorläufige Ergebnisse
}

Authors

Affiliation
J.-H. Klingler, R. Sircar, M. H. Deininger, C. Scheiwe, E. Kogias, U. Hubbe

Department of Neurosurgery, Freiburg University Medical Center, Freiburg
Key words
- spine
- surgery
- metastases instrumentation
- percutaneous
- interventional procedures

eingereicht 4.12.2011

akzeptiert 26.11.2012

Bibliography

DOI http://dx.doi.org/

10.1055/s-0032-1330443

Published online: 7.3.2013

Fortschr Röntgenstr 2013; 185:

340-350 @ Georg Thieme

Verlag KG Stuttgart . New York . ISSN 1438-9029

\section{Correspondence Dr. Jan-Helge Klingler \\ Department of Neurosurgery, Freiburg University Medical Center \\ Breisacher Str. 64 \\ 79106 Freiburg \\ Germany \\ jan-helge.klingler@uniklinik- freiburg.de \\ Tel.: ++ 49/7 61/27050010 \\ Fax: ++ 49/7 61/27050240}

\section{Zusammenfassung \\ v}

Ziel: Bewertung von Wirksamkeit und Sicherheit der perkutanen Vesselplastie zur Behandlung pathologischer Wirbelkörperfrakturen der thorakolumbalen Wirbelsäule bei ausgewählten Patienten. Material und Methoden: Elf pathologische Wirbelkörperfrakturen bei 9 Patienten wurden mittels Vesselplastie (Vessel- $\mathrm{X}^{\circledR}$, MAXXSPINE) behandelt. Neun der 11 Wirbelkörper $(81,8 \%)$ wiesen eine deutliche Beteiligung der Wirbelkörperhinterwand $(>30 \%)$ auf. Klinische und radiologische (CT) Parameter wurden vor und 3 Monate nach der Therapie erhoben.

Ergebnisse: Der durchschnittliche Schmerzwert der VAS verbesserte sich signifikant von präzu postoperativ $(6,9 \pm 2,2$ vs. $3,7 \pm 2,3 ; \mathrm{p}<0,05)$ ebenso wie der ODI $(59,7 \pm 19,2$ vs. $40,3 \pm 24,0 \%$; $\mathrm{p}<0,05)$. Die körperliche Summenskala des SF-36 verbesserte sich durch die Operation signifikant $(19,2 \pm 8,0$ vs. $31,0 \pm 16,5 ; \mathrm{p}<0,05)$. Symptomatische Zementextravasation oder operationsassoziierte Komplikationen wurden nicht beobachtet. Drei Patienten wurden initial mit gleichzeitiger minimalinvasiver Stabilisierung mittels Fixateur interne behandelt. Ein Patient musste sich einer minimalinvasiven Stabilisierung mittels Fixateur interne 4 Monate nach der Vesselplastie unterziehen, da der behandelte Wirbelkörper weiter eingebrochen war.

Schlussfolgerung: Ausgehend von diesen vorläufigen Ergebnissen scheint die Vesselplastie sogar bei Beteiligung der Wirbelkörperhinterwand eine erwägenswerte Therapieoption für pathologische Wirbelkörperfakturen darzustellen. Ausgewählte Tumorpatienten können von der Vesselplastie als minimalinvasives Verfahren zur Stabilisierung des frakturierten Wirbelkörpers, Schmerzbehandlung sowie Verbesserung der körperlichen Funktion und Lebensqualität profitieren. Langfristige prospektive Studien mit einer größeren Fallzahl sind erforderlich, um diese Ergebnisse zu validieren.

\section{Abstract \\ $\nabla$}

Purpose: To evaluate the effectiveness and safety of percutaneous vesselplasty in pathological vertebral fractures of the thoracolumbar spine in selected tumor patients.

Materials and Methods: Eleven pathological vertebral fractures in nine patients were treated with vesselplasty (Vessel- $\mathrm{X}^{\circledR}$, MAXXSPINE). Nine of eleven vertebras $(81.8 \%)$ had major posterior wall deficiency $(>30 \%)$. Clinical and radiological (CT) measures were obtained before and 3 months after the procedure.

Results: The mean VAS improved significantly from preoperative to postoperative $(6.9 \pm 2.2$ to $3.7 \pm 2.3 ; \mathrm{p}<0.05)$, as did the ODI $(59.7 \% \pm 19.2 \%$ to $40.3 \% \pm 24.0 \%$; $\mathrm{p}<0.05$ ). The physical component summary of the SF-36 was significantly improved by the operation $(19.2 \pm 8.0$ to $31.0 \pm 16.5$; $\mathrm{p}<0.05$ ). Symptomatic cement leakage or other operation-associated complications were not observed. Three patients were primarily treated with concomitant minimally invasive stabilization via fixateur interne. One patient had to undergo minimally invasive stabilization via fixateur interne 4 months after vesselplasty due to further collapse of the treated vertebral body.

Conclusion: From these preliminary results, vesselplasty appears to be a treatment option worth considering in pathological vertebral fractures, even in the case of posterior wall deficiency. Selected tumor patients might benefit from vesselplasty as a minimally invasive procedure for stabilization of the fractured vertebra, pain control, and improvement in body function and quality of life. Long-term prospective studies with a larger sample size are required to validate these results. 


\section{Introduction}

\section{$\nabla$}

Pathological vertebral fractures (PVF) caused by metastatic disease or myeloma frequently result in intense pain associated with reduced mobility and quality of life. Typical treatment regimens include analgesic drugs, open instrumented surgery, radiotherapy, and chemotherapy. Open and extensive instrumented surgery has disadvantages including higher infection rates, wound healing disturbances, higher blood loss, intense postoperative back pain, slower recovery times, and longer hospital stays compared to minimally invasive approaches $[1,2]$. In this respect, minimally invasive procedures might also be beneficial for tumor patients with metastatic disease of the spine.

Patients with osteoporotic compression fractures, osteolytic tumors, and bone metastasis have already been treated with minimally invasive, percutaneous augmentation techniques such as vertebroplasty and conventional balloon kyphoplasty [3-6]. The main principle of conventional balloon kyphoplasty is to create a steady void inside a fractured vertebral body to be filled with bone cement after removing the balloon, which is possible in osteoporotic compression fractures. In contrast, the soft tumor tissue in PVF is supposed to recollapse after removal of the initially inflated and then reduced balloon so that a steady void is not left behind ( Fig. 1a, b). Thus, the procedure results in a common vertebroplasty ( $\bullet$ Fig. 1c). In this context, the injected cement follows the path of least resistance in an uncontrolled manner. A promising solution for this problem may be provided by a modified kyphoplasty technique named vesselplasty that was initially introduced for the treatment of osteoporotic compression fractures [7-9]. In vesselplasty, a non-stretchable balloon with small pores is introduced into the vertebral body and inflated by injecting viscous bone cement into the balloon itself. This prevents a recollapse of the soft tumor tissue. Intended cement penetration through the small pores of the balloon provides for interdigitation with the surrounding spongious bone. The filled vesselplasty balloon is left as an expanded vertebral body implant ( $\bullet$ Fig. 2). Vesselplasty was reported to be effective in the therapy of osteoporotic compression fractures (evidence grade III) [7-9].

The present study evaluates the safety and effectiveness of the new concept of percutaneous vesselplasty for the treatment of PVF in selected tumor patients.

\section{METHODS \\ $\nabla$}

\section{Patient selection}

Patients admitted to our department with tumorous disease of the thoracic and lumbar spine between March 2009 and April 2010 were considered suitable for vesselplasty if the criteria shown in $\bullet$ Table 1 applied. The conducted operations are summarized in $\bullet$ Fig. 3. After surgical treatment, the patients were presented to the oncologist/radiotherapist for adjuvant chemotherapy/radiotherapy.

The local ethics committee approved the study. Informed consent was obtained from the patients.

\section{Procedure}

All vesselplasty procedures were performed using the Vessel- $\mathrm{X}^{\circledR}$ Bone Filling Container System (MAXXSPINE, Bad Schwalbach,
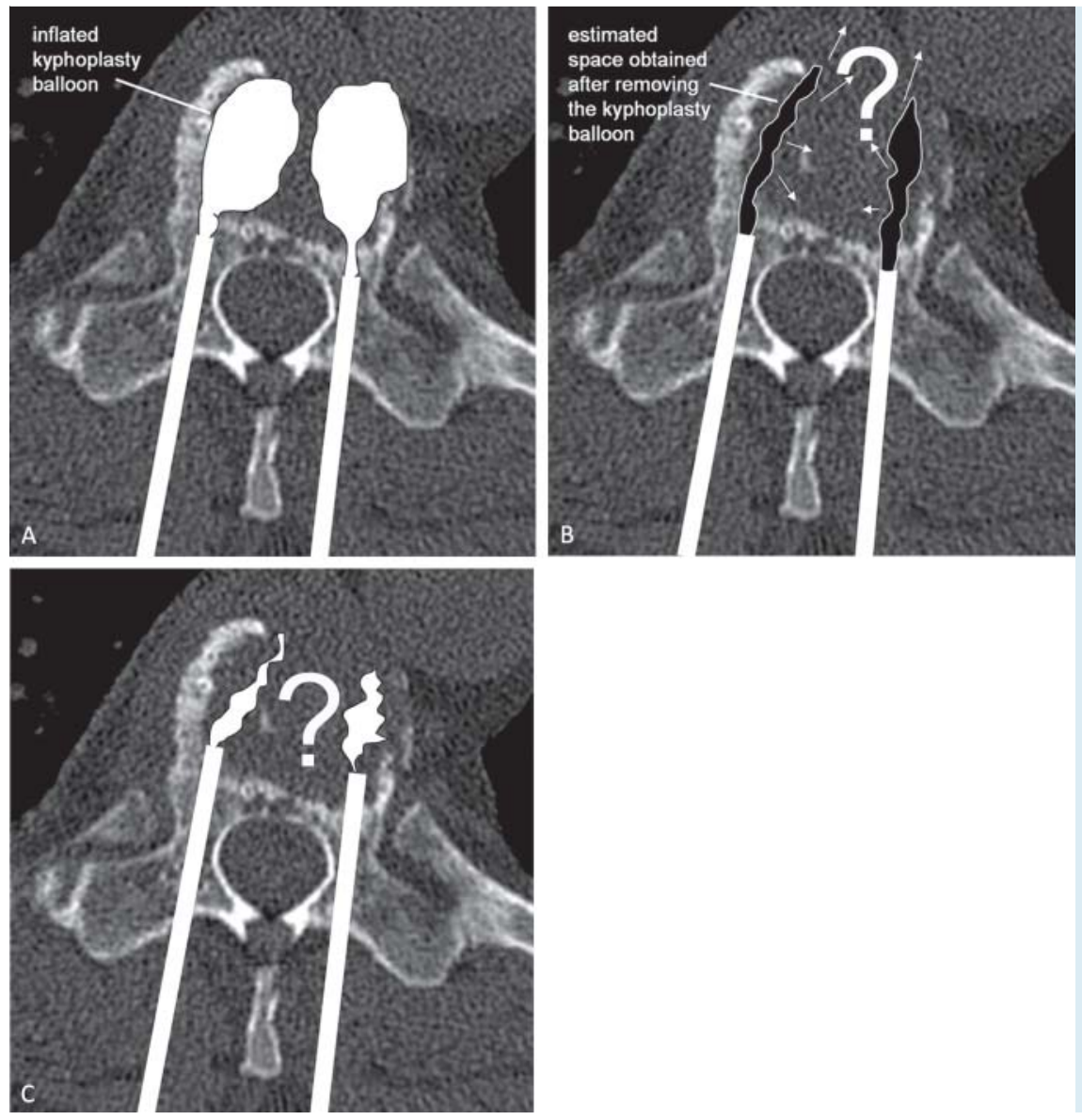

Fig. 1 Conventional balloon kyphoplasty a, b and vertebroplasty $\mathbf{c}$ in PVF. Schematic drawings have been superimposed on the same axial CT slice to illustrate the following assumptions: in conventional balloon kyphoplasty, removing the inflated balloon a from pathological vertebral fractures (PVF) might result in a recollapse of the surrounding soft tumor tissue and might not leave behind a steady void ( $\mathbf{b}$, black area). Thus, the injected cement would follow the path of least resistance in an uncontrolled manner (b, arrows) and may leak through vertebral wall deficiencies. Similarly in vertebroplasty c, the cement is injected in the soft tumor tissue in an uncontrolled manner.

Abb. 1 Konventionelle Ballonkyphoplastie a, b und Vertebroplastie $\mathbf{c}$ in PVF. Schematische Zeichnungen im jeweils selben axialen CT sollen folgende Annahmen verdeutlichen: Bei der konventionellen Ballonkyphoplastie kann das Entfernen des expandierten Ballons a aus einem Wirbelkörper mit pathologischer Fraktur (PVF) zu einem erneuten Zusammenfallen des umgebenden weichen Tumorgewebes führen, ohne einen stabilen Hohlraum zurückzulassen (b, schwarzer Bereich). Hierdurch würde der eingebrachte Zement unkontrolliert den Weg des geringsten Widerstands nehmen (b, Pfeile) und durch nicht intakte Knochenstrukturen eine Zementextravasation verursachen. Bei der Vertebroplastie $\mathbf{c}$ wird der Zement in ähnlicher Weise unkontrolliert in weiches Tumorgewebe eingebracht. 
Germany). Each patient was placed in the prone position under general anesthesia. A Jamshidi needle (10-gauge) was inserted through the pedicle of the fractured vertebra under C-arm fluoroscopy monitoring and advanced into the fractured body until its tip just crossed the posterior wall by about $3 \mathrm{~mm}$. After installation of the cannula tube ( $\bullet$ Fig. 2a), a manual drill was used to forge a path through the vertebral body ( $\bullet$ Fig. 2b). After removal of the drill, the reduced vesselplasty balloon was inserted through the canal into the vertebral body, while being sure to fixate the tip and/or the connecting device of the deflated balloon in firm bony structures of the vertebra ( $\bullet$ Fig. 2c). The cement delivery system was connected, and the prepared bone cement (SpinePlex ${ }^{\circledR}$, Stryker, Duisburg, Germany) was progressively injected into the vesselplasty balloon ( $\boldsymbol{F}$ Fig. $\mathbf{2 d}$ ) that is provided with numerous small pores with a size of $100 \mu \mathrm{m}$. The cement filling procedure ( $2-3 \mathrm{ml}$ per balloon) was performed under fluoroscopic guidance and continued until an adequate expansion of the vesselplasty balloon and an intended cement penetration through the pores was achieved for interdigitation with the surrounding spongious bone ( $\bullet$ Fig. 2e). Thereafter, the expanded vesselplasty balloon was disconnected from the introducer $(\bullet$ Fig. 2e), and the instruments were removed leaving behind the filled and expanded vesselplasty balloon in the vertebral body ( $\bullet$ Fig. $2 f$ ).

We used a bipedicular approach in eight PVFs and a unipedicular approach in two PVFs, depending on the individual anatomical condition. In one patient with a large unilateral tumor and an intraspinal tumor extent of $73 \%$ (see below, Radiographic assessment), we implanted two balloons via a unipedicular approach during minimally invasive decompression surgery.
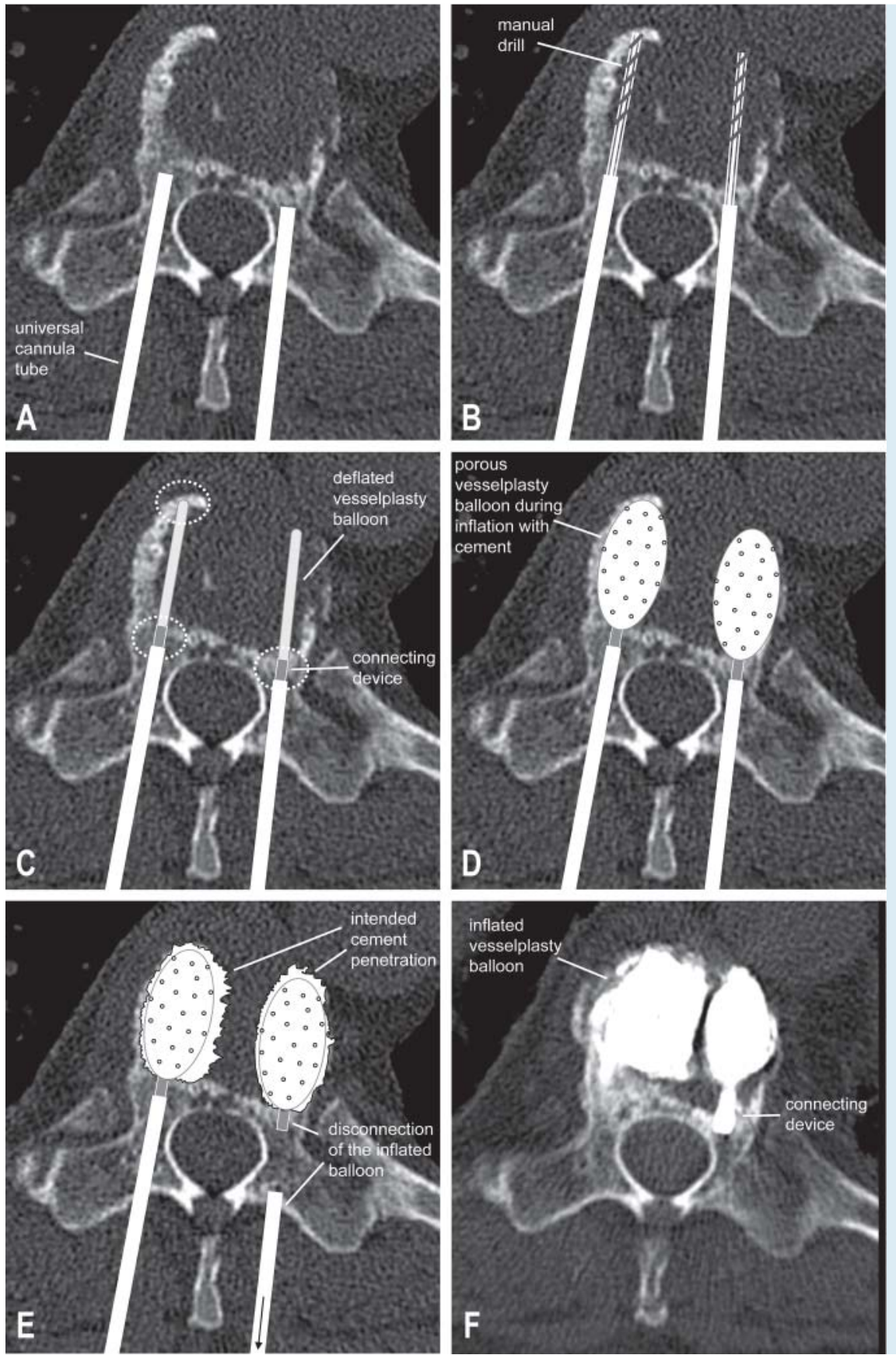

Fig. 2 Concept of vesselplasty. a-e Schematic drawings have been superimposed on the same axial CT slice to illustrate the concept of vesselplasty. f Corresponding postoperative result of the treated vertebra. After the universal cannula tube $\mathbf{a}$ is installed and a path is forged through the vertebral body with a manual drill $\mathbf{b}$, the vesselplasty balloon is introduced in a deflated configuration c. The tip and/or the connecting device are fixated in firm bony structures for tight hold (c, dashed circles). While inflating the porous balloon with cement $\mathbf{d}$, the intended cement penetration through the small pores contributes to interdigitation with the surrounding bone $\mathbf{e}, \mathbf{f}$. The expanded balloon is disconnected at the connecting device (which is anchored to the bone) and left as a vertebral body implant e, f.

Abb. 2 Konzept der Vesselplastie. a-e Schematische Zeichnungen im jeweils selben axialen CT verdeutlichen das Konzept der Vesselplastie. f Korrespondierendes postoperatives Ergebnis des behandelten Wirbelkörpers. Nach Einbringen der Arbeitskanüle a wird mit einem Handbohrer im Wirbelkörper ein Arbeitskanal geschaffen $\mathbf{b}$ und der Vesselplastie-Ballon in kompakter Konfiguration eingeführt c. Die Spitze und/oder der Konnektor werden für einen festen Halt in stabilen Knochenstrukturen verankert (c, gestrichelte Kreise). Beim Auffüllen des feinporigen Ballons mit Zement $\mathbf{d}$ tritt eine beabsichtigte Menge Zement durch die feinen Poren aus, um zur Befestigung am umliegenden Knochen beizutragen e, f. Der expandierte Ballon wird am Konnektor (welcher am Knochen verankert

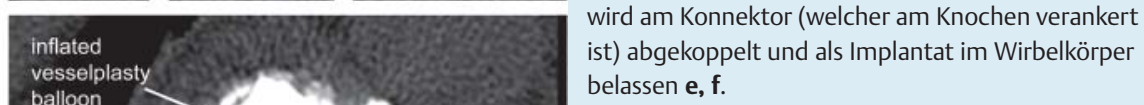
belassen $\mathbf{e}, \mathbf{f}$. 
Table 1 Patient Selection Criteria for Vesselplasty. ${ }^{1}$

Tab. 1 Auswahlkriterien für Vesselplastie. ${ }^{2}$

\begin{tabular}{|c|c|}
\hline inclusion criteria & exclusion criteria \\
\hline $\begin{array}{l}\text { imaging evidence of a PVF on } \\
\text { radiography, CT, and MRI and } \\
\text { pain localized to the fracture } \\
\text { level } \\
\text { (in vertebral fractures of nonspe- } \\
\text { cific or unknown origin, an intra- } \\
\text { operative biopsy confirmed the } \\
\text { presence of metastatic disease or } \\
\text { myeloma) }\end{array}$ & $\begin{array}{l}\text { exclusion of surgically curative } \\
\text { PVF } \\
\text { (e. g. solitary PVF with surgical } \\
\text { treatment including total tumor } \\
\text { resection, vertebral body replace- } \\
\text { ment and fixateur interne) }\end{array}$ \\
\hline $\begin{array}{l}\text { intractable and disabling pain } \\
\text { due to the PVF }\end{array}$ & \multirow{4}{*}{$\begin{array}{l}\text { exclusion of paraparesis/para- } \\
\text { plegia due to intraspinal tumor } \\
\text { masses necessitating urgent } \\
\text { decompression surgery } \\
\text { (a larger intraspinal tumor extent } \\
\text { that did not lead to neurological } \\
\text { deficits was not considered a con- } \\
\text { traindication, but concomitant } \\
\text { minimally invasive dorsal decom- } \\
\text { pression was considered) }\end{array}$} \\
\hline $\begin{array}{l}\text { life expectancy more than } \\
3 \text { months }\end{array}$ & \\
\hline suitability for general anesthesia & \\
\hline $\begin{array}{l}\text { PVF not treatable with vertebro- } \\
\text { plasty or conventional balloon } \\
\text { kyphoplasty due to major bone } \\
\text { destruction of the vertebra and/ } \\
\text { or posterior wall deficiency }\end{array}$ & \\
\hline
\end{tabular}

\section{Data collection}

We collected the clinical characteristics of each patient such as age, sex, primary tumor, and level of the PVF ( $\bullet$ Table 2 ) as well as technical details of the operation ( $\bullet$ Fig. 3). Data regarding complications of the operation including cement leakage, infection, bleeding, neural compression or following operations were also collected.

The patients' subjective condition before and 3 months after the operation was obtained with the Oswestry Disability Index (ODI), the visual analog scale (VAS) with a range of $0-10$ (0: no pain; 10: worst possible pain), and the Short Form 36 Health Survey (SF-36) to assess levels of pain, body function, and quality of life before and after the procedure.

To evaluate patient satisfaction with the postoperative result, the Patient Satisfaction Index (PSI) was applied at the 3-month follow-up [10]. The PSI is a modified subitem of the North American Spine Society outcome questionnaire. It is scored as follows: 1) „Surgery met my expectations“; 2) „I did not improve as much as I had hoped but I would undergo the same operation for the same results“; 3) „Surgery helped but I would not undergo the same operation for the same results“; and 4) „I am the same or worse as compared to before surgery".

Questionnaires, fluoroscopy and CT scans of the treated and adjacent levels were obtained preoperatively and with a minimum 3month follow-up. The mean follow-up was 23.3 weeks. All patients were alive at the time of follow-up.

\section{Radiographic assessment}

Preoperative thin-sliced CT scans were available in all patients. We determined the extent of posterior wall deficiency in coronal reconstructed CT slices through the posterior wall by calculating the percentage of hypodense areas divided by the total area of the posterior wall ( $\bullet$ Fig.4a). We measured a mean posterior wall deficiency of $49 \% \pm 27 \%$ (range: $14-85 \%$ ) by means of a ruptured posterior wall or osteolytic changes of the posterior wall.

At the level of greatest spinal canal stenosis, we measured the extent of intraspinal tumor in axial reconstructed CT slices or MRI
Table 2 Clinical Characteristics of the 9 Patients with Pathological Vertebral Fracture.

Tab. 2 Klinische Daten der 9 Patienten mit pathologischer Wirbelkörperfraktur.

\begin{tabular}{|lr|}
\hline characteristic & no. (\%) \\
\hline age $(y)$ & $1(11.1)$ \\
\hline$-46-55$ & $0(0)$ \\
\hline$-56-65$ & $6(66.7)$ \\
\hline$-66-75$ & $2(22.2)$ \\
\hline$-76-85$ & $71 \pm 9$ yrs \\
\hline average age & \\
\hline sex & $5(55.6)$ \\
\hline - male & $4(44.4)$ \\
\hline - female & \\
\hline no. of treated fractures per patient & $7(77.8)$ \\
\hline - 1 & $2(22.2)$ \\
\hline - 2 & \\
\hline location of the 11 fractures & $1(9.1)$ \\
\hline - T4 & $1(9.1)$ \\
\hline - T8 & $4(36.4)$ \\
\hline - T10 & $4(36.4)$ \\
\hline - T12 & $1(9.1)$ \\
\hline - L5 & \\
\hline primary tumor & $3(33.3)$ \\
\hline - multiple myeloma/plasmocytoma & $2(22.2)$ \\
\hline - lung cancer & $2(22.2)$ \\
\hline - breast cancer & $1(11.1)$ \\
\hline - renal cell carcinoma & $1(11.1)$ \\
\hline - bladder cancer & \\
\hline
\end{tabular}

scans (contrast-enhanced T1-weighted sequences) by calculating the percentage of the intraspinal tumorous area divided by the area of the spinal canal. The mean intraspinal tumor extent was $37 \% \pm 30 \%$ (range: $0-73 \%$ ). Three PVFs showed no intraspinal tumor invasion (0\%) ( $\bullet$ Fig. 5 ), and three PVFs exhibited an intraspinal tumor extent of more than two-thirds of the spinal canal (in detail 70\%, 73\%, 73\%,॰ Fig. 5). Consequently, two of these underwent vesselplasty with concomitant minimally invasive decompression surgery. In this subgroup of palliative patients without severe neurological deficits, we did not perform decompression surgery in the third patient due to the underlying renal cell carcinoma, which typically results in higher intraoperative morbidity [11].

Correlation analysis showed that a higher posterior wall deficiency was a significant predictor for a higher extent of intraspinal tumor $\left(\mathrm{R}^{2}=0.478, \mathrm{p}=0.018\right)$ ( $\bullet$ Fig. 5 ).

Postoperative CT scans at follow-up were used to assess cement leakages and new vertebral fractures. The degree of kyphosis and vertebral body height were measured in CT scans for lack of fluoroscopies. The degree of kyphosis was assessed by measuring the angle from the superior endplate of the vertebral body above the treated PVF to the inferior endplate of the vertebral body below. Vertebral body height was measured according to Flors et al. [9] using digital calipers in the anterior, central, and posterior portions of the vertebral body.

\section{Statistical analysis}

Differences in the mean levels of pain, body function, and quality of life as well as vertebral body height and kyphotic angle before and after the procedure were compared with the paired, twotailed Student's t-test. Pearson's correlation was used for regression analysis to evaluate the relationship between posterior wall 


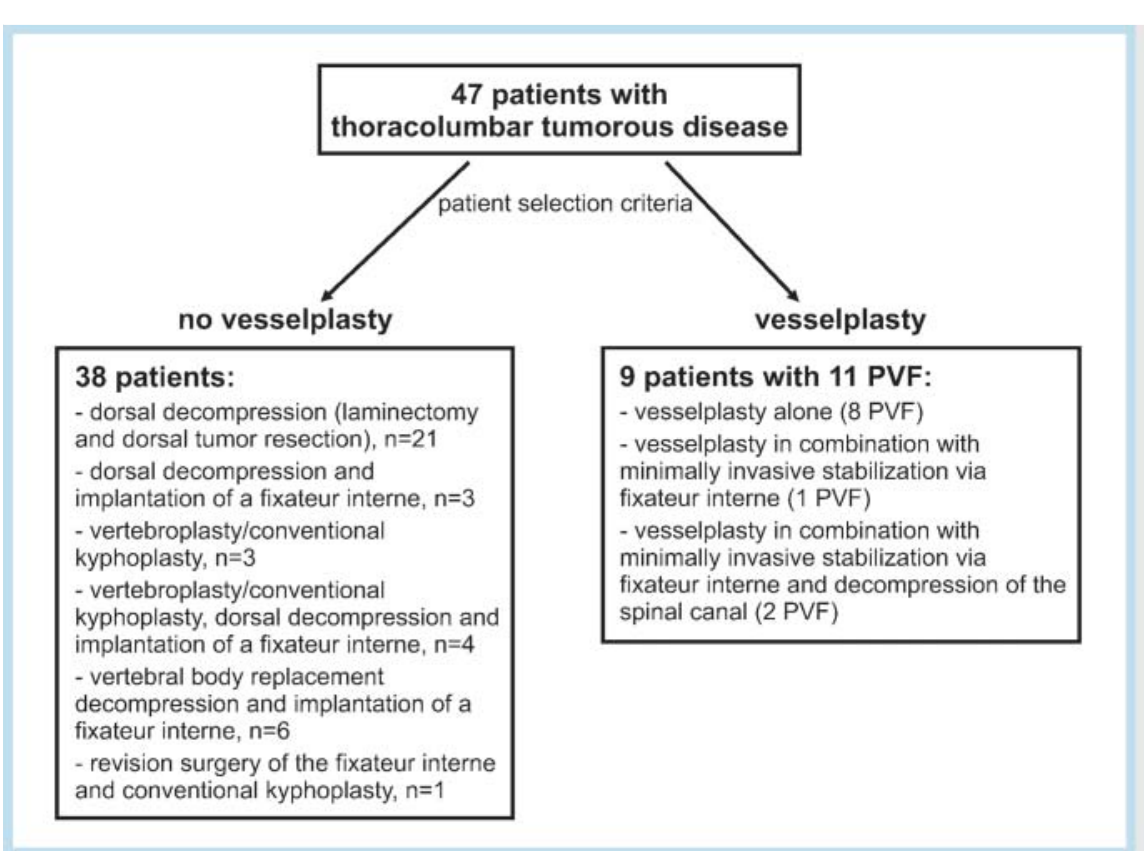

Fig. 3 Treatment modalities. Forty-seven patients with tumorous disease of the thoracic and lumbar spine were operated in the time frame of the study. Nine patients with eleven pathological vertebral fractures (PVF) were treated with vesselplasty according to the patient selection criteria ( $($ Table 1 ).Three patients treated with vesselplasty presented with extensive tumorous destruction of the vertebra including pedicles and facet joints leading to segmental instability that necessitated stabilization of both the anterior and posterior aspect of the spine. Therefore, these patients were concomitantly treated with minimally invasive stabilization via fixateur interne ranging from the vertebra above the PVF to the vertebra below the PVF.

deficiency and the extent of intraspinal tumor. P-values $<0.05$ were considered to be statistically significant.

\section{Results}

$\nabla$

Postoperatively, no neurological deterioration occurred. No symptomatic operation-associated or medical complications were observed.

At follow-up examination, eight patients presented without any motor deficit, and preoperative sensor disturbances in two patients improved. One patient presented with an ameliorated paraparesis from preoperative grade 3 to grade 4 at follow-up according to the Medical Research Council grading system.

\section{Radiographic outcome}

Fluoroscopy and CT scans were performed at 3-month follow-up. CT scans at 3-month follow-up revealed no cement leakage in 5/ 11 PVFs (45.5\%). Epidural cement leakage occurred in 1/11 PVFs (9.1\%) with the largest extent of posterior wall deficiency ( $85 \%$ ), paravertebral cement leakage in 4/11 PVFs (36.4\%), and intradiscal cement leakage in 3/11 PVFs (27.3\%) ( $\bullet$ Fig. 4). A favorable radiological outcome is shown in $\bullet$ Fig. 6b. All patients reported pain relief postoperatively ( $\bullet$ Fig. 7, $\odot$ Table 3 ).

$6 / 9$ patients $(66.7 \%)$ had no additional fractures at 3-month follow-up. $1 / 9$ patients (11.1\%) showed a new remote vertebral body fracture. $2 / 9$ patients $(22.2 \%)$ showed a further collapse of the treated vertebra. One of the latter patients had no symptoms
Abb. 3 Behandlungsmodalitäten. 47 Patienten mit Tumorerkrankung der thorakolumbalen Wirbelsäule wurden im Zeitraum der Studie operiert. Neun Patienten mit 11 pathologischen Wirbelkörperfrakturen (PVF) wurden entsprechend der Auswahlkriterien ( $\bullet$ Tab. 1) mittels Vesselplastie behandelt. Drei der mit Vesselplastie behandelten Patienten wiesen eine weitgehende knöcherne Destruktion des Wirbelkörpers inklusive Pedikel und Facettengelenke auf. Dies führte zu segmentaler Instabilität und erforderte eine Stabilisierung des anterioren sowie posterioren Aspekts der Wirbelsäule. Daher wurden diese Patienten gleichzeitig mit einem minimalinvasiven Fixateur interne versorgt, welcher vom Wirbelkörper über der PVF bis zum Wirbelkörper unter der PVF reichte. at all and needed no further operative treatment until now. The other patient redeveloped local pain without any neurological deficit and underwent minimally invasive stabilization via fixateur interne 120 days after the first operation leading to a satisfying outcome again. No adjacent vertebra collapse was revealed in any patient.

The average decrease in vertebral body height after vesselplasty was $1.0 \pm 2.0 \mathrm{~mm}$ in the anterior portion, $0.4 \pm 1.1 \mathrm{~mm}$ in the central portion, and $0.5 \pm 1.0 \mathrm{~mm}$ in the posterior portion without showing any significant difference. Despite vesselplasty, kyphotic angulation increased significantly by $2.3 \pm 3.9^{\circ}(\mathrm{p}=0.043)$.

\section{Questionnaires}

The mean VAS pain score improved significantly by $46 \%(\mathrm{p}<0.05)$ ( $\bullet$ Fig. 7, $\odot$ Table 3). The bodily pain domain of the SF-36 showed a numeric improvement ( $\mathrm{p}=0.062$ ) ( $\bullet$ Fig. 8, $\diamond$ Table 3 ).

The ODI scores as a measurement of body function decreased statistically significantly after treatment $(\mathrm{p}<0.05)$ ( $\bullet$ Fig. 9, $\odot$ Table 3). The SF-36 confirmed the statistically significant improvement of the functional outcome in the physical function domain $(\mathrm{p}<0.05)$ and the physical component summary $(\mathrm{p}<0.05)$ ( $\diamond$ Fig. 8, $\diamond$ Table 3). The social function of the SF-36 yielded a numeric improvement $(p=0.057)$. All other scores of the SF-36 showed numeric improvement without reaching statistical significance ( $\bullet$ Fig. 8, $\bullet$ Table 3 ).

The PSI as an evaluation of patient satisfaction with the postoperative result yielded the following answers: $4 \times 1,3 \times 2$, and $1 \times 4$ ( $\mathrm{n}=8$ patients $)$. 

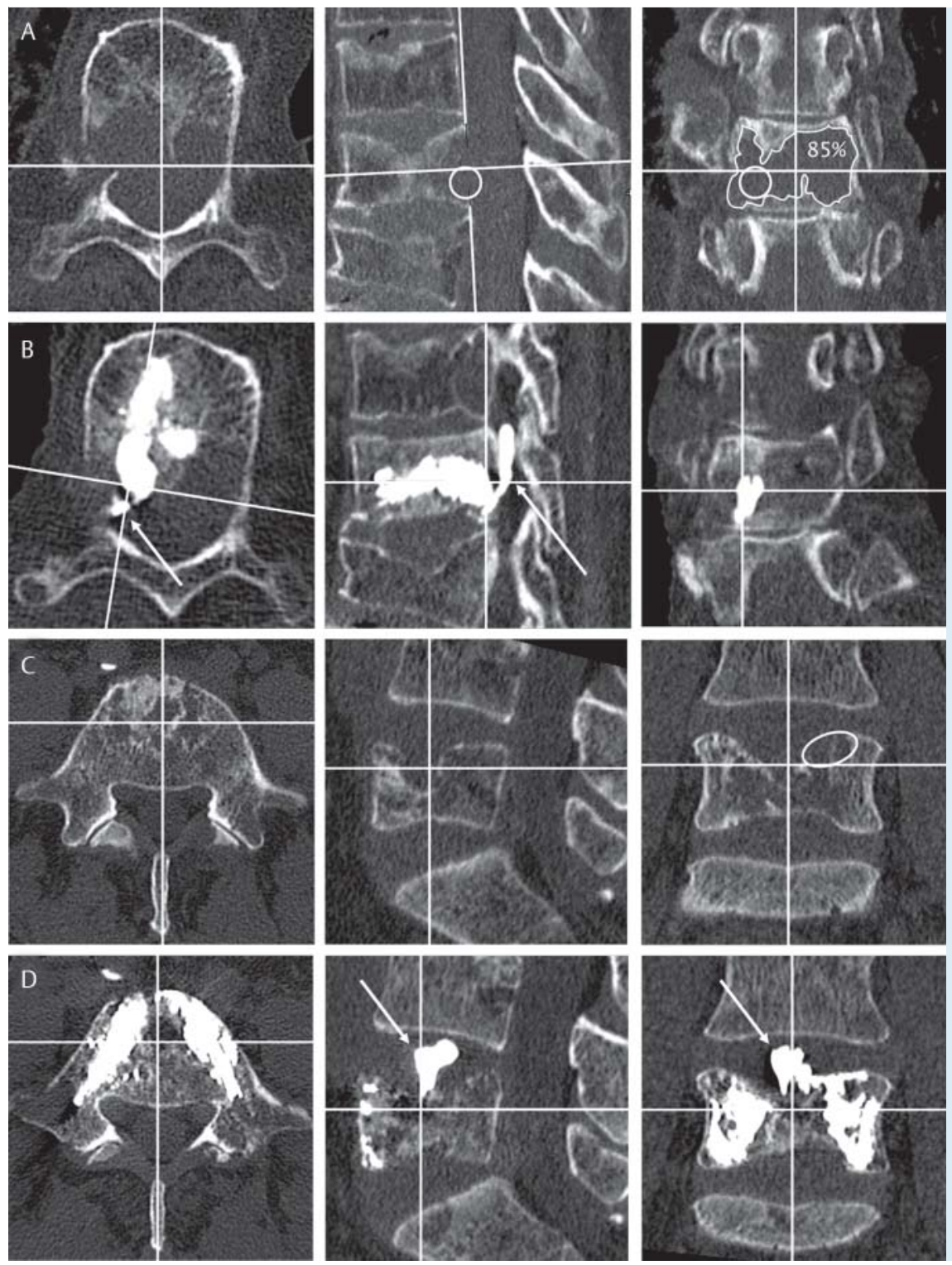

Fig. 4 Cement leakage.Triplanar CT scans of two patients with pathological vertebral fracture (PVF) due to breast cancer (patient I: PVF at T10, preoperative $\mathbf{a}$ and postoperative images $\mathbf{b}$; patient II: PVF at L5, preoperative $\mathbf{c}$ and postoperative images d). The measurement technique in a comprehensive extent of posterior wall deficiency ( $85 \%$ ) is displayed in the coronal slice a. Encircled a, $\mathbf{c}$ are the penetration sites of epidural $\mathbf{b}$ and intradiscal $\mathbf{d}$ cement leakage (arrows).

Abb. 4 Zementextravasation. Triplanare CT von 2 Patienten mit pathologischer Wirbelkörperfraktur (PVF), ausgehend von jeweils einem Mammakarzinom (Patient I: PVF von T10, präoperativ a und postoperativ b; Patient II: PVF von L5, präoperativ c und postoperativ d). Die Messtechnik bei einer ausgedehnten Beteiligung der Wirbelkörperhinterwand $(85 \%)$ wird in der koronaren Rekonstruktion a veranschaulicht. Eingekreist sind die Durchtrittsstellen der epiduralen b bzw. intradiskalen d Zementextravasationen (Pfeile).

\section{Discussion}

$\nabla$

Patients with PVF admitted to our department had been previously excluded from primary radiotherapy according to the „wait and watch” policy. They experienced extensive restrictions in daily activities prior to treatment. Of these, the patients selected for vesselplasty represent a further subgroup ( $\bullet$ Table 1 ).

Surgical stabilization of the fractured vertebra for pain relief has to be as gentle as possible on these patients $[3,12]$. Percutaneous augmentation techniques are a promising and least invasive approach for stabilizing the ventral column of the fractured segment. We considered vesselplasty as the most appropriate treatment method for the selected patients with PVF and superior to vertebroplasty and conventional balloon kyphoplasty due to vast destruction of the vertebra and deficiencies of the posterior wall.

Three patients were treated primarily with vesselplasty and concomitant minimally invasive stabilization via fixateur interne. These patients showed extensive tumorous destruction of the vertebra including pedicles and facet joints leading to instability of the spine. Stabilization both of the ventral and dorsal aspect of the affected segment was necessitated to warrant safe mobiliza- tion of these patients without a corset. Even more than in a curative situation, we aimed to be as minimally invasive as possible in this subgroup of patients with a reduced general condition. In this respect, vesselplasty was used for stabilization of the ventral aspect of the spine instead of vertebral body replacement (which we would have preferred in a curative situation). For stabilization of the dorsal aspect of the spine, a percutaneous, minimally invasive dorsal fixateur interne was used.

Minimally invasive techniques were shown to be beneficial in consideration of wound healing disturbances, infection rates, blood loss during surgery, recovery time after surgery, and duration of the hospital stay [1, 2]. All of these aspects gain importance for tumor patients with limited life expectancy.

\section{Clinical outcome}

There are very few, only non-randomized reports on the efficacy and safety of kyphoplasty in PVF. Several studies found a significant improvement in pain and body function after vertebroplasty and kyphoplasty in PVF [4, 12 - 15]. These results are in line with our results with vesselplasty ( $\bullet$ Fig. 7-9, $\bullet$ Table 3), which demonstrated significant improvement in the VAS from pre- to post- 


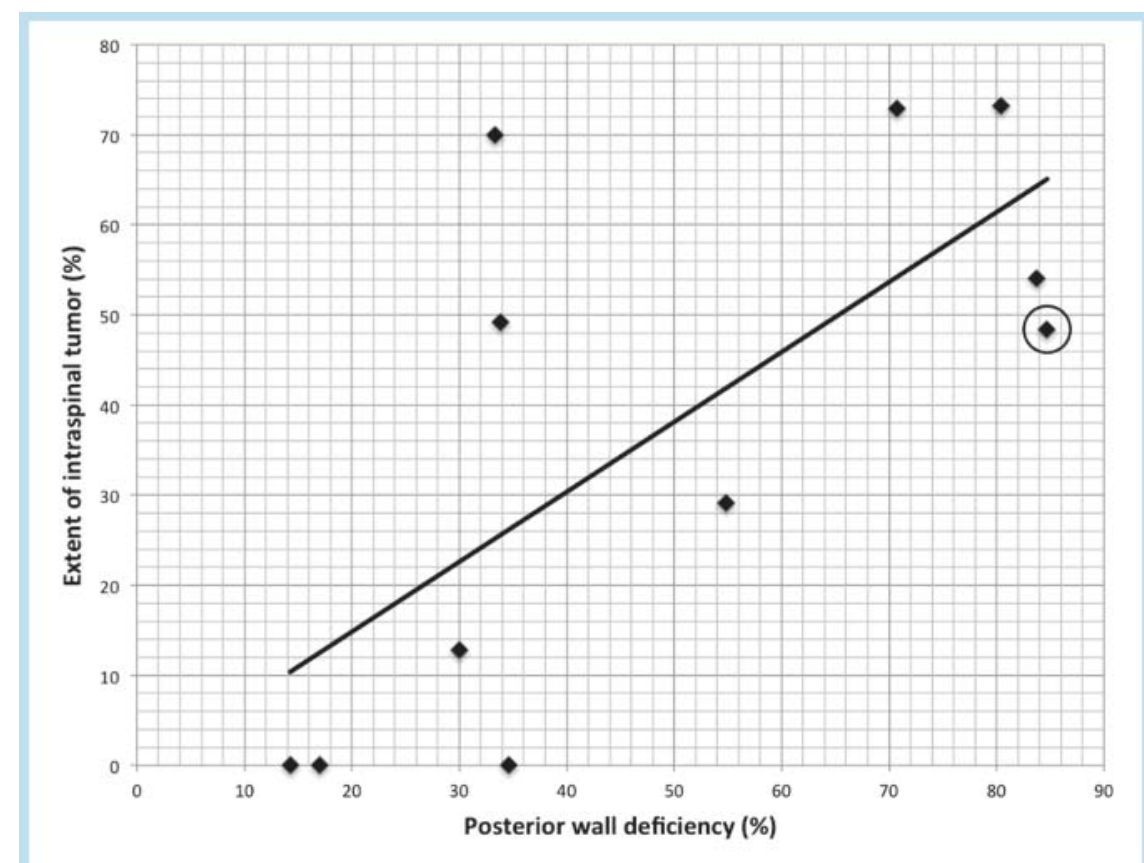

Fig. 5 Posterior wall deficiency and extent of intraspinal tumor. Chart showing the extent of posterior wall deficiency and intraspinal tumor of eleven treated PVFs (pathological vertebral fractures). The regression line displays the statistically significant correlation $(p<0.05)$ between these two characteristics. The PVF with an epidural cement leakage and the highest posterior wall deficiency is encircled (see also $\bullet$ Fig. 4a, b).

Abb.5 Beteiligung der Wirbelkörperhinterkante und Ausmaß des intraspinalen Tumoranteils. Das Diagramm zeigt das Ausmaß der Beteiligung der Wirbelkörperhinterkante und des intraspinalen Tumoranteils der 11 behandelten PVF (pathologische Wirbelkörperfraktur). Die Regressionsgerade veranschaulicht die statistisch signifikante Korrelation $(p<0.05)$ dieser beiden Merkmale. Die PVF mit epiduraler Zementextravasation und ausgeprägtesten Beteiligung der Wirbelkörperhinterkante ist eingekreist (siehe auch $\bullet$ Abb. 4a, b).
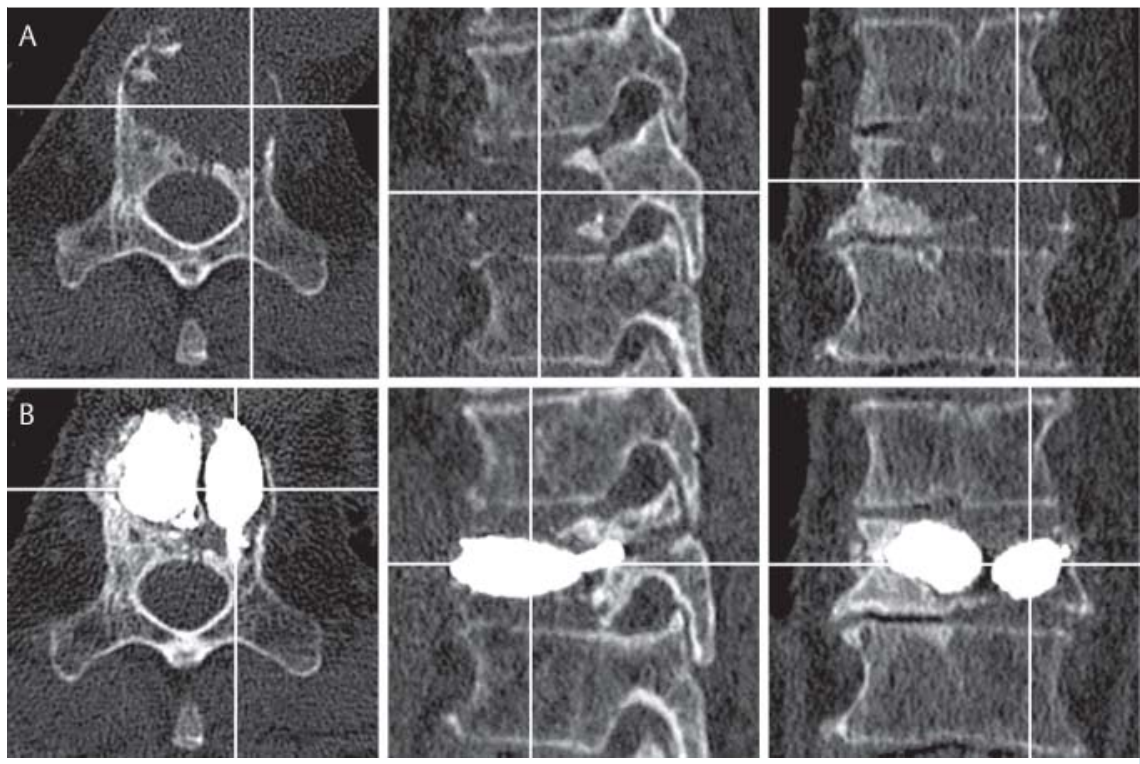

Fig. 6 Favorable radiological outcome in PVF with wall deficiency. Pathological vertebral fracture (PVF) due to plasmocytoma at T10. a Preoperative triplanar CT scan showing extensive deficiency of the anterior and lateral wall. b Postoperative triplanar CT scan showing a favorable radiological outcome with two expanded vesselplasty balloons without cement leakage, but with intended cement penetration through the small pores of the balloon for interdigitation with the surrounding bone.

Abb. 6 Günstiges radiologisches Ergebnis bei PVF mit Beteiligung der Wirbelkörperhinterwand. Pathologische Wirbelkörperfraktur (PVF) durch Plasmozytom von T10. a Präoperatives triplanares CT mit ausgedehnter Beteiligung der anterioren und lateralen Wirbelkörperwand. b Postoperatives triplanares CT mit günstigem radiologischem Ergebnis mit 2 expandierten Vesselplastie-Ballons ohne Zementextravasation, aber beabsichtigter Zementperforation durch die feinen Poren des Ballons zur Verzahnung mit der umgebenden Knochenstruktur.

treatment as well as numeric improvement in the bodily pain domain of the SF-36 ( $p=0.062)$. Flors et al. [9] used vesselplasty in 25 patients with osteoporotic/traumatic vertebral fractures and 4 patients with PVF. They reported a worse outcome on the PVF subgroup than in the osteoporotic/traumatic subgroup with the PVF subgroup experiencing less pain relief (37 vs. 65\%) and showing no improvement in the use of analgesics or mobility. In comparison, our patients stated pain relief of $46 \%$ (VAS). Moreover, the functional outcome was significantly improved in the ODI, the physical function domain and the physical component summary of the SF-36. Pain and function were also improved in the subgroup of patients with vesselplasty alone, i.e., without additional stabilization via fixateur interne $(n=6, p<0.05$, data not shown). With improvement in pain and function, the social function (SF-36) also improved, but without being significant $(p=0.057)$. Interestingly, no significant improvement in the general health domain of the SF-36 was found, which is a previously described phenomenon and may reflect progression of the primary malignant disease [13].

\section{Cement leakage}

Percutaneous delivery of cement into a fractured vertebra carries the risk of extensive cement leakages, especially in vertebroplasty [16-18]. The specific advantage of balloon kyphoplasty and vesselplasty in particular is presumed to be safer bone cement delivery with a lower cement leakage rate [13].

Flors et al. [9] used vesselplasty in 32 osteoporotic/traumatic vertebral fractures and 5 PVFs and reported one intradiscal cement 
leakage $(2.7 \%)$ without clinical repercussion. However, they neither specified the radiographic assessment (CT or fluoroscopy) nor the subgroup in which the leakage occurred.

The incidence of cement leakage in osteoporotic compression fractures has been reported in up to $81 \%$ with vertebroplasty [19] and in up to $21.8 \%$ with conventional balloon kyphoplasty [20]. Mendel et al. [4] reviewed 28 articles using vertebroplasty and 12 articles using conventional balloon kyphoplasty in PVF. They reported an incidence of cement leakage in $9.2 \%$ to $139 \%$ with vertebroplasty and $0-26.3 \%$ with conventional balloon kyphoplasty. In this context, multiple cement leakage areas per treated vertebra resulted in an incidence of more than $100 \%$. The authors summarized that vertebroplasty entailed a 4 times higher cement leakage rate and more often caused symptomatic cement leakages requiring surgical decompression compared to conventional balloon kyphoplasty in PVF. Interestingly, cement leakage does not depend on the etiology of PVF, e.g. myeloma vs. metastasis [13]. The advantage of balloon kyphoplasty was attributed to the greater viscosity of the cement and the creation of a cavity allowing cement delivery with lower pressure [21]. We assume that in the case of soft tumor tissue in PVF, the creation of a steady void is unlikely. Soft tumor tissue is supposed to recollapse after removal of the initially inflated and then reduced balloon so that a steady void is not left behind ( $\boldsymbol{0}$ Fig. 1a, b). Thus, the procedure results in a common vertebroplasty ( $\bullet$ Fig. 1c). Therefore, the injected cement follows the path of least resistance in an uncontrolled manner ( $\boldsymbol{\bullet}$ Fig. $\mathbf{1}$ ). In contrast, the reduced vesselplasty balloon is filled with bone cement itself and consequently creates a steady cement augmentation in the tumorous destructed vertebra ( $\bullet$ Fig. 2 ). This prevents a recollapse of the soft tumor tissue.

At first glance, the incidence of cement leakage in 6/11 (54.5\%) treated PVFs in our study appears surprisingly high and conflicts with the abovementioned advantages of vesselplasty. It is noteworthy that $81.8 \%$ of the treated vertebras had deficiencies of the posterior wall of at least 30\% ( $\bullet$ Fig. 4a, 5). Moreover, the anterior and lateral cortex of the fractured vertebra also showed wall deficiency to a considerable extent ( $\boldsymbol{\bullet}$ Fig. 6a). We observed that ce- ment leaked typically through a cortex with broken wall integrity ( $\odot$ Fig. 4b, d). In PVF with wall deficiency, conventional balloon kyphoplasty was judged unsuitable due to the risk of extruding wall

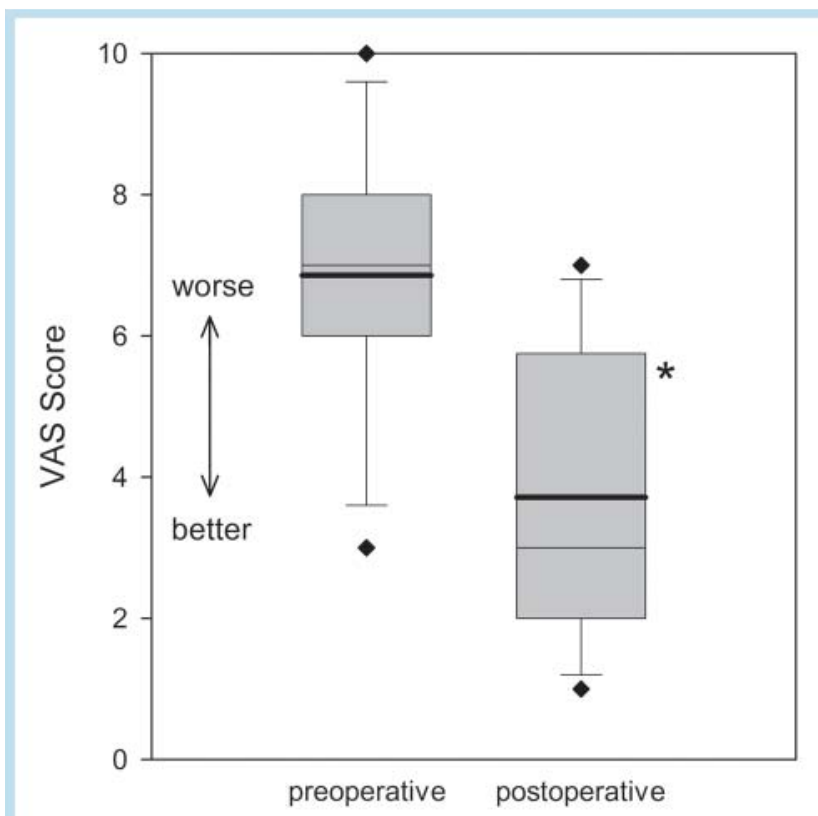

Fig. 7 Visual analog scale (VAS).Box plot showing the median (thin line in the box), mean (thick line in the box), 25th and 75th percentiles as vertical boxes. Whiskers above and below the box indicate the 90th and 10th percentiles. The outliers are graphed as diamonds. ${ }^{*} \mathrm{p}<0.05$ compared to preoperative value (paired, two-tailed Student's t-test).

Abb.7 Visuelle Analogskala (VAS). Das Boxplot stellt den Median (dünne Linie in der Box), Mittelwert (dicke Linie in der Box), die 25. und 75. Perzentile mittels vertikaler Box dar. Die Whisker ober- und unterhalb der Box zeigen die 90. und 10. Perzentile an. Ausreißer sind als Rauten dargestellt. ${ }^{*} \mathrm{p}<0,05$ im Vergleich zum präoperativen Wert (gepaarter, zweiseitiger Student's t-test).

Table 3 Mean Improvement of VAS, ODI and SF-36 Scores. ${ }^{1}$

Tab. 3 Durchschnittliche Verbesserung der VAS, des ODI und SF-36. ${ }^{2}$

\begin{tabular}{llllllllllllll}
\hline & \multicolumn{9}{c}{ SF-36 } & & & & \\
& VAS & ODI & PF & RP & BP & GH & VT & SF & RE & MH $^{\text {PCS }^{3}}$ & MCS $^{3}$ \\
\hline preoperative & 6.9 & 59.7 & 14.2 & 0.0 & 16.9 & 46.6 & 24.3 & 33.7 & 66.7 & 53.1 & 19.2 & 46.9 \\
& \pm 2.2 & $\pm 19.2 \%$ & \pm 14.6 & \pm 0.0 & \pm 23.0 & \pm 18.6 & \pm 12.7 & \pm 24.9 & \pm 47.1 & \pm 20.1 & \pm 8.0 & \pm 11.3 \\
\hline 3-month follow-up & 3.7 & 40.3 & 47.1 & 20.8 & 46.1 & 52.1 & 38.6 & 60.7 & 88.8 & 68.6 & 31.0 & 53.3 \\
& $\pm 2.3^{4}$ & $\pm 24.0 \%^{4}$ & $\pm 37.3^{4}$ & \pm 40.1 & $\pm 32.3^{5}$ & \pm 23.7 & \pm 17.0 & $\pm 25.4^{5}$ & \pm 27.4 & \pm 22.3 & $\pm 16.5^{4}$ & \pm 5.1 \\
\hline
\end{tabular}

${ }^{1}$ The table shows the means with standard deviations preoperatively and at follow-up. In the VAS (ranging from $0-10$ ) and ODI (ranging from $0-100 \%$ ), lower values represent a better outcome. In the SF-36 (ranging from 0 - 100), higher values represent a better outcome. VAS - Visual analog scale, ODI - Oswestry Disability Index, SF-36 - Short Form 36 Health Survey, PF - physical function, RP - role physical, BP - bodily pain, GH - general health, VT - vitality, SF - social function, RE - role emotional, MH - mental health, PCS physical component summary, MCS - mental component summary.

${ }^{2}$ Die Tabelle zeigt die Mittelwerte mit Standardabweichung präoperativ sowie während des Follow-up. Beim VAS (von 0 - 10 reichend) und ODI (von 0 - $100 \%$ reichend) bedeuten niedrigere Werte ein besseres Outcome. Beim SF-36 (von 0 - 100 reichend) bedeuten höhere Werte ein besseres Outcome. VAS - Visuelle Analogskala, ODI - Oswestry Disability Index, SF-36 - Short Form 36 Health Survey, PF - Körperliche Funktionsfähigkeit, RP - Körperliche Rollenfunktion, BP - Körperlicher Schmerz, GH - Allgemeine Gesundheitswahrnehmung, VT - Vitalität, SF - Soziale Funktionsfähigkeit, RE - Emotionale Rollenfunktion, MH - Psychisches Wohlbefinden, PCS - Körperliche Summenskala, MCS - Psychische Summenskala.

${ }^{3}$ PCS and MCS are normalized to a mean of 50 and standard deviation of 10 .

PCS und MCS sind auf einen Mittelwert von 50 mit einer Standardabweichung von 10 normalisiert.

${ }^{4} \mathrm{P}<0.05$ compared to preoperative value (paired, two-tailed Student's t-test).

$\mathrm{P}<0,05$ im Vergleich zum präoperativen Wert (gepaarter, zweiseitiger Student's t-test).

${ }^{5} 0.05<\mathrm{p}<0.07$ compared to preoperative value (paired, two-tailed Student's t-test).

$0,05<p<0,07$ im Vergleich zum präoperativen Wert (gepaarter, zweiseitiger Student's t-test). 


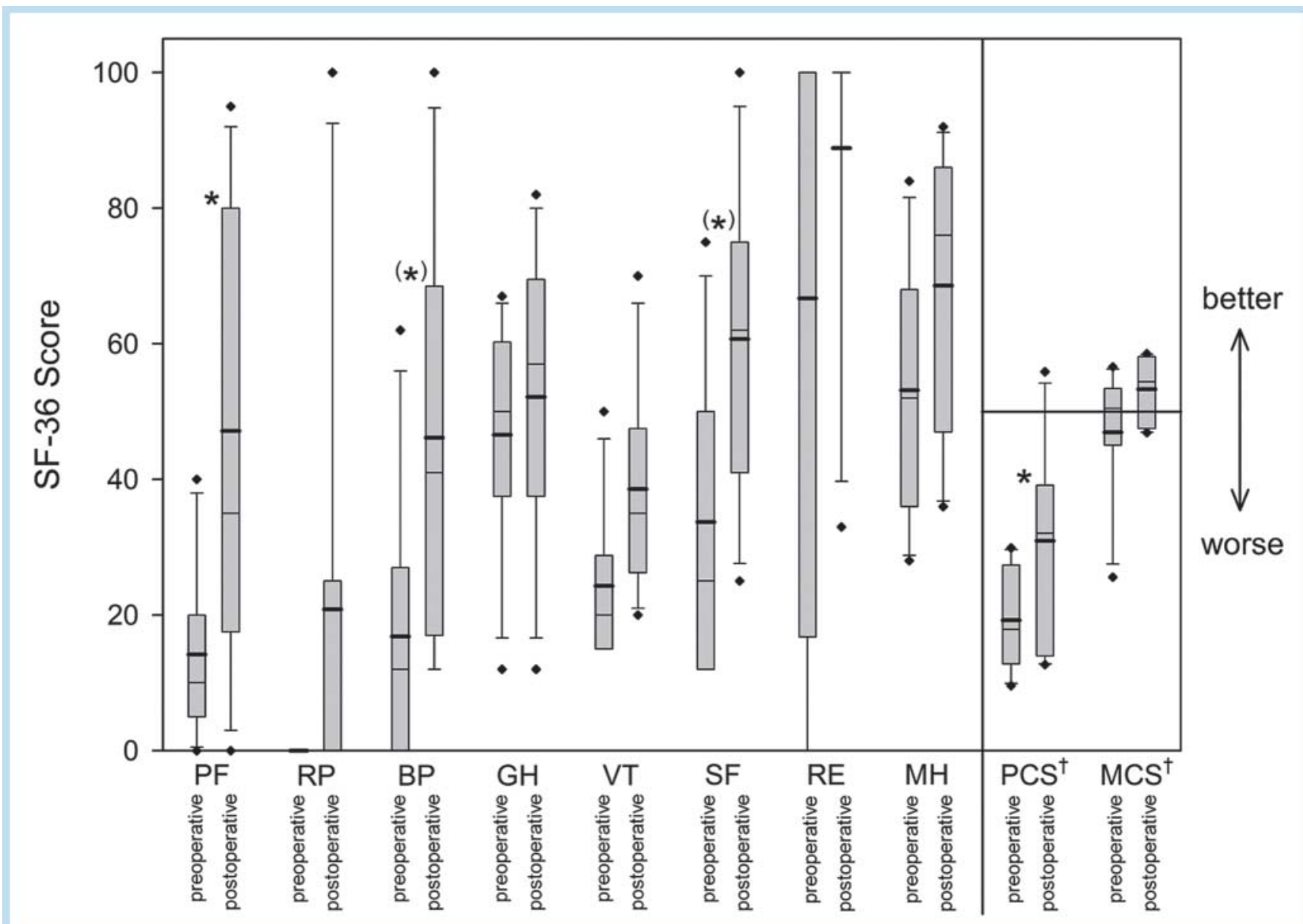

Fig. 8 Short Form 36 Health Survey (SF-36).Box plot showing the median (thin line in the box), mean (thick line in the box), 25th and 75th percentiles as vertical boxes. Whiskers above and below the box indicate the 90 th and 10 th percentiles. The outliers are graphed as diamonds. PF - physical function, RP - role physical, BP - bodily pain, $\mathrm{GH}$ - general health, VT - vitality, SF - social function, RE - role emotional, $\mathrm{MH}$ - mental health. PCS - physical component summary, MCS - mental component summary. $\dagger$ PCS and MCS are normalized to a mean of 50 and standard deviation of 10 (indicated by horizontal line). ${ }^{*} p<0.05$ compared to preoperative value (paired, two-tailed Student's t-test). $\left({ }^{*}\right) 0.05<p<0.07$ compared to preoperative value (paired, two-tailed Student's t-test).
Abb. 8 Short-Form 36 Health Survey (SF-36). Das Boxplot stellt den Median (dünne Linie in der Box), Mittelwert (dicke Linie in der Box), die 25. und 75. Perzentile mittels vertikaler Box dar. Die Whisker ober- und unterhalb der Box zeigen die 90. und 10. Perzentile an. Ausreißer sind als Rauten dargestellt. PF - Körperliche Funktionsfähigkeit, RP - Körperliche Rollenfunktion, BP - Körperlicher Schmerz, GH - Allgemeine Gesundheitswahrnehmung, VT - Vitalität, SF - Soziale Funktionsfähigkeit, RE - Emotionale Rollenfunktion, MH - Psychisches Wohlbefinden. PCS - Körperliche Summenskala, MCS - Psychische Summenskala. †PCS und MCS sind auf einen Mittelwert von 50 (horizontale Linie) mit einer Standardabweichung von 10 normalisiert. ${ }^{*} p<0,05$ im Vergleich zum präoperativen Wert (gepaarter, zweiseitiger Student's t-test). $\left({ }^{*}\right) 0,05<p<0,07$ im Vergleich zum präoperativen Wert (gepaarter, zweiseitiger Student's t-test). fragments or tumor into the canal by the inflation of the balloon [15]. Though other authors performed conventional balloon kyphoplasty in PVF with wall deficiency, they did not dwell on the extent of wall deficiency and the PVF did not show intraspinal tumor involvement $[12,22]$. Cement leakage rates in these studies were $4.7 \%$ assessed in fluoroscopy [12] and 37.5\% assessed in CT [22]. Saliou et al. [23] performed vertebroplasty explicitly in PVF with posterior wall deficiency and intraspinal tumor involvement and reported an incidence of cement leakage of $117 \%$ (implying multiple cement leakage areas per treated PVF). In this respect, the complication rate of cement delivery in PVF is higher than in osteoporotic compression fractures [24-26].

Another crucial aspect is that postoperative detection of cement leakage is underestimated in fluoroscopy compared to CT [19]. A study on the detection of leakages showed 1.1 leakages per vertebra on CT and only in one-third of vertebras on lateral fluoro- scopy [27]. Thus, studies solely using fluoroscopy [21, 28] could show false lower cement leakage rates in comparison with our study using CT. Intraoperatively, however, CT is not an adequate imaging modality, as it does not provide real-time imaging.

\section{Symptomatic cement leakage}

All nine patients experienced pain relief postoperatively ( $\bullet$ Fig. 7,

- Table 3). However, we cannot exclude that intradiscal cement leakage in three patients contributed to residual back pain. Except for this uncertainty, no cement leakage was symptomatic. Available studies with higher numbers reported up to $13.5 \%$ symptomatic cement leakages in PVF (e.g. with radicular pain or neurological deficits) necessitating decompression surgery in up to $5 \%$ in vertebroplasty $[4,24]$, while there were none in conventional balloon kyphoplasty $[4,13]$. We also did not observe any neurologic deterioration, e.g. by further tumor dislocation 


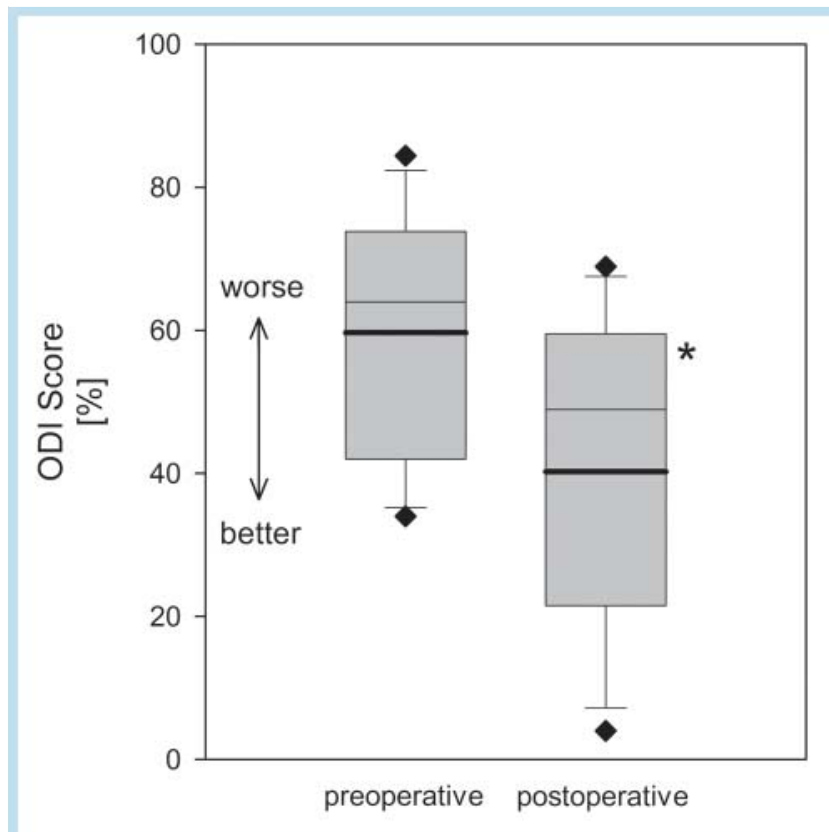

Fig. 9 Oswestry Disability Index (ODI). Box plot showing the median (thin line in the box), mean (thick line in the box), 25th and 75th percentiles as vertical boxes. Whiskers above and below the box indicate the 90th and 10th percentiles. The outliers are graphed as diamonds. ${ }^{*} p<0.05$ compared to preoperative value (paired, two-tailed Student's t-test)

Abb.9 Oswestry-Disability-Index (ODI). Das Boxplot stellt den Median (dünne Linie in der Box), Mittelwert (dicke Linie in der Box), die 25. und 75. Perzentile mittels vertikaler Box dar. Die Whisker ober- und unterhalb der Box zeigen die 90. und 10. Perzentile an. Ausreißer sind als Rauten dargestellt. ${ }^{*}<0,05$ im Vergleich zum präoperativen Wert (gepaarter, zweiseitiger Student's t-test).

through posterior wall deficiencies. But we strongly consider and advise concomitant decompression of the spinal canal if the extent of intraspinal tumor is greater than $60 \%$. In one patient with a large extent of intraspinal tumor, however, we refrained from decompression surgery due to a highly vascularized PVF (metastasis of a renal cell carcinoma). Nevertheless, this patient was neurologically unimpaired postoperatively.

\section{Vertebral body height and pathological kyphosis}

In contrast to osteoporotic fractures, restoring vertebral body height and correcting pathological kyphosis had no priority in our subgroup of palliative tumor patients with PVF.

Other authors reported an average increase in vertebral body height of about half a millimeter in the case of vesselplasty [9] or conventional balloon kyphoplasty [29] and an initial reduction of the kyphotic angle by $0.9^{\circ}$ [29]. Furthermore, the initial restoration of vertebral height and the correction of pathological kyphosis returned to preoperative levels one year or longer after conventional balloon kyphoplasty in PVF [14, 15, 21, 29]. Like other authors [29], we consider these slight changes clinically irrelevant in palliative tumor patients.

\section{Medical complications}

Medical complications due to vertebral augmentation procedures are diverse and involve adverse reactions to bone cement, anaphylaxis, hypotension during surgery, pneumothorax, pulmonary embolism, epidural hematoma, arterial injury, anterior spinal artery syndrome, and death [30 - 32]. Pulmonary embolism caused by cement emboli is a known complication in vertebral augmentation techniques [32]. Barragán-Campos et al. [25] reported pulmonary embolism in $1.7 \%$ of cases with a mortality of $0.8 \%$ for vertebroplasty in PVF. Bouza et al. [13] reported no pulmonary embolism for kyphoplasty in PVF. Mendel et al. [4] reported in their review a medical complication rate of $1.3 \%(0-$ $7.1 \%)$ for vertebroplasty and $0.3 \%(0-0.5 \%)$ for kyphoplasty in PVF. We observed no symptomatic operation-associated or medical complications in our study using vesselplasty in eleven PVFs.

\section{New vertebral body fractures during follow-up}

We observed no adjacent vertebra fracture after vesselplasty in a relatively short observation period, but $1 / 9$ patients with a new remote fracture and 2/9 patients with a new collapse of the treated vertebra.

One of the latter patients had no symptoms at all and needed no further operative treatment until now. The other patient redeveloped local pain without any neurological deficit and underwent minimally invasive stabilization via dorsal fixateur interne 120 days after the first operation leading to a satisfying outcome again. Critically reviewing the case of this patient, we regard the new collapse of the treated vertebra as an application error. With our current experience, we would have treated the patient initially with vesselplasty and concomitant dorsal stabilization via fixateur interne due to extensive bony destruction of the fractured vertebra including a pedicle with consequent instability of the spine.

Two studies by Pflugmacher et al. [29,33] evaluated kyphoplasty for PVF due to metastases with a two-year follow-up [29] and multiple myeloma with a one-year follow-up [33]. Both studies comprise 147 procedures and showed adjacent fractures in $7.1 \%$ of the patients (6/85) requiring operative correction in half of the patients.

\section{Conclusion}

\section{$\nabla$}

Vertebroplasty and conventional balloon kyphoplasty are currently used to treat PVF with varying success concerning clinical outcome and complication rate. Especially in PVF with extensive posterior wall deficiency, conventional augmentation techniques encounter difficulties with respect to the feasibility of controlled cement delivery. From our preliminary results, vesselplasty as new minimally invasive technique appears to be a reliable and effective treatment option for selected patients with PVF, especially in the case of wall deficiencies. In awareness of the limitations of our study (absence of a control group, retrospective design, limited numbers, short follow-up), prospective, randomized studies comparing vesselplasty with other augmentation techniques in PVF are required to define the roles of these treatment options in spine surgery.

\section{Abbreviations \\ $\nabla$ \\ VAS Visual analog scale \\ ODI Oswestry Disability Index \\ PSI Patient Satisfaction Index \\ PVF Pathological vertebral fracture \\ SF-36 Short Form 36 Health Survey}




\section{References}

1 Park Y, Ha JW. Comparison of one-level posterior lumbar interbody fusion performed with a minimally invasive approach or a traditional open approach. Spine (Phila Pa 1976) 2007; 32: 537-543

2 Patel NP, Birch BD, Dement SE et al. The mini-open anterolateral approach for degenerative thoracolumbar disease. Clin Neurol Neurosurg 2010; $112: 853-857$

3 Pflugmacher R, Beth P, Schroeder RJ et al. Balloon kyphoplasty for the treatment of pathological fractures in the thoracic and lumbar spine caused by metastasis: one-year follow-up. Acta Radiol 2007; 48: 89-95

4 Mendel E, Bourekas E, Gerszten P et al. Percutaneous techniques in the treatment of spine tumors: what are the diagnostic and therapeutic indications and outcomes? Spine (Phila Pa 1976) 2009; 34: S93-100

5 Pflugmacher R, Kandziora F, Schröder $R$ et al. Vertebroplastie und Kyphoplastie bei osteoporotischen Wirbelkörperfrakturen - Eine prospektive Analyse der Einjahresergebnisse. Fortschr Röntgenstr 2005; 177: $1670-1676$

6 Ludtke CW, Kamusella P, Andresen R. Schmerzbehandlung bei pathologischer Os-sacrum-Fraktur mittels CT-gesteuerter Ballonsakroplastie. Fortschr Röntgenstr 2012; 184: 578-580

7 Zheng Z, Luk KD, Kuang $G$ et al. Vertebral augmentation with a novel Vessel-X bone void filling container system and bioactive bone cement. Spine (Phila Pa 1976) 2007; 32: 2076-2082

8 Tempesta V, Cannata G, Ferraro G et al. The New Vessel-X Kyphoplasty For Vertebral Compression Fractures: 2-Year Follow-Up Of 136 Levels. Las Vegas: American Academy of Orthopaedic Surgeons Annual Meeting; 2009

9 Flors L, Lonjedo E, Leiva-Salinas $C$ et al. Vesselplasty: a new technical approach to treat symptomatic vertebral compression fractures. Am J Roentgenol 2009; 193: $218-226$

10 Daltroy LH, Cats-Baril WL, Katz JN et al. The North American spine society lumbar spine outcome assessment Instrument: reliability and validity tests. Spine (Phila Pa 1976) 1996; 21: 741 - 749

11 Rehak S, Krajina A, Ungermann L et al. The role of embolization in radical surgery of renal cell carcinoma spinal metastases. Acta Neurochir 2008; 150: 1177-1181

12 Zou J, Mei X, Gan M et al. Kyphoplasty for spinal fractures from multiple myeloma. J Surg Oncol 2010; 102: 43-47

13 Bouza C, Lopez-Cuadrado T, Cediel P et al. Balloon kyphoplasty in malignant spinal fractures: a systematic review and meta-analysis. BMC Palliat Care 2009; 8: 12

14 Masala S, Lunardi P, Fiori $R$ et al. Vertebroplasty and kyphoplasty in the treatment of malignant vertebral fractures. J Chemother 2004; 16: 30-33

15 Dudeney S, Lieberman IH, Reinhardt MK et al. Kyphoplasty in the treatment of osteolytic vertebral compression fractures as a result of multiple myeloma. J Clin Oncol 2002; 20: $2382-2387$

16 Birkenmaier C, Seitz S, Wegener B et al. Acute paraplegia after vertebroplasty caused by epidural hemorrhage. A case report. J Bone Joint Surg Am 2007; 89: 1827-1831
17 Lin CC, Shen WC, Lo YC et al. Recurrent pain after percutaneous vertebroplasty. Am J Roentgenol 2010; 194: 1323-1329

18 Harrington $K D$. Major neurological complications following percutaneous vertebroplasty with polymethylmethacrylate: a case report. J Bone Joint Surg Am 2001; 83: 1070 - 1073

19 Venmans A, Klazen CA, van Rooij WJ et al. Postprocedural CT for perivertebral cement leakage in percutaneous vertebroplasty is not necessary - results from VERTOS II. Neuroradiology 2011; 53: 19-22

20 Taylor RS, Fritzell P, Taylor RJ. Balloon kyphoplasty in the management of vertebral compression fractures: an updated systematic review and meta-analysis. Eur Spine J 2007; 16: 1085-1100

21 Fourney DR, Schomer DF, Nader R et al. Percutaneous vertebroplasty and kyphoplasty for painful vertebral body fractures in cancer patients. J Neurosurg 2003; 98: 21-30

22 Qian Z, Sun Z, Yang H et al. Kyphoplasty for the treatment of malignant vertebral compression fractures caused by metastases. J Clin Neurosci 2011; 18: 763 - 767

23 Saliou G, Kocheida el M, Lehmann P et al. Percutaneous vertebroplasty for pain management in malignant fractures of the spine with epidural involvement. Radiology 2010; 254: $882-890$

24 Cotten A, Dewatre F, Cortet B et al. Percutaneous vertebroplasty for osteolytic metastases and myeloma: effects of the percentage of lesion filling and the leakage of methyl methacrylate at clinical follow-up. Radiology 1996; 200: 525-530

25 Barragan-Campos HM, Vallee JN, Lo D et al. Percutaneous vertebroplasty for spinal metastases: complications. Radiology 2006; 238: 354-362

26 Deramond H, Depriester C, Galibert P et al. Percutaneous vertebroplasty with polymethylmethacrylate. Technique, indications, and results. Radiol Clin North Am 1998; 36: 533-546

27 Schmidt R, Cakir B, Mattes T et al. Cement leakage during vertebroplasty: an underestimated problem? Eur Spine J 2005; 14: 466-473

28 Georgy BA. Clinical experience with high-viscosity cements for percutaneous vertebral body augmentation: occurrence, degree, and location of cement leakage compared with kyphoplasty. Am J Neuroradiol 2010; 31: 504-508

29 Pflugmacher R, Taylor R, Agarwal A et al. Balloon kyphoplasty in the treatment of metastatic disease of the spine: a 2-year prospective evaluation. Eur Spine J 2008; 17: 1042 - 1048

30 Tsai YD, Liliang PC, Chen $\mathrm{HJ}$ et al. Anterior spinal artery syndrome following vertebroplasty: a case report. Spine (Phila Pa 1976) 2010; 35 E134-E136

31 Cosar M, Sasani M, Oktenoglu T et al. The major complications of transpedicular vertebroplasty. J Neurosurg Spine 2009; 11: 607-613

32 Schwarz M, Reimer P, Schulte B. Die pulmonalarterielle Zementembolie - eine mögliche Komplikation nach Kyphoplastie. Fortschr Röntgenstr 2011; 183: $172-173$

33 Pflugmacher R, Kandziora F, Schroeder RJ et al. Percutaneous balloon kyphoplasty in the treatment of pathological vertebral body fracture and deformity in multiple myeloma: a one-year follow-up. Acta Radiol 2006; 47: 369-376 